\title{
THE GRAY-CROWNED ROSY FINCH IN MANITOBA AND VICINITY
}

BRIAN N. TURNER and PETER TAYLOR, Pinawa, Manitoba, ROE 1 LO.

The Gray-crowned Rosy Finch is a medium-sized fringillid with a range stretching from the islands of the Bering Sea, to as far south as centraleastern California. ${ }^{49}$ The breeding range in Canada includes southwestern Alberta, all of British Columbia except the northeastern quarter, and extends to the central Yukon. The easternmost limit of the usual winter range includes southern Alberta and extreme southwestern Saskatchewan. Curiously, for a bird which typically spends its summer at the higher levels of mountain ranges in the Rockies and farther west, the first rosy finch to be discovered, and subsequently described, was a specimen taken near Carlton House, Saskatchewan, in May 1827 (Swainson and Richardson ${ }^{41}$, cited in Bent ${ }^{4}$ ). Our sighting of this species in extreme southeastern Manitoba in November 1978 prompted a search for other Manitoba records, and ultimately to a summary of all known records of the species east of the normal winter range in the northern Great Plains.

A Gray-crowned Rosy Finch spent the 1978-79 winter at Pinawa, Manitoba, where it was seen on many occasions by several experienced observers from 20 November to 30 March. Since these observations constitute only the ninth record of this species in Manitoba in nearly 90 years (Table 1), and are the only series of sightings throughout a winter, they are described here in some detail.

The Pinawa bird was first seen by Nelda Turner at a feeding station on
20 November 1978 . It accompanied a flock of Evening Grosbeaks, which are common visitors to Pinawa feeding stations. Having identified the bird from guides at hand, and realizing that it was unusual, she reported the sighting to the senior author and on his advice obtained a series of photographs. ${ }^{931}$ Two days later, R. W. Knapton, W. Neily and K. DeSmet arrived from Winnipeg to verlfy the record. They obtained further photographs (Fig. 1) and observed the bird closely to determine that it belonged to the subspecies tephrocotis.

The arrival of about $20 \mathrm{~cm}$ of permanent snow on 12 November, combined with unseasonably cold temperatures, likely prompted the finch to seek out a feeding station. The overnight temperature was near $-30^{\circ} \mathrm{C}$, some 20 degrees colder than usual, so that a high-density, fat-rich food supply would be welcome. However, although this was the second coldest winter of the century in southern Manitoba, conditions were no more severe than those usually encountered in parts of the Gray-crowned Rosy Finch's winter range. The Pinawa bird was subsequently observed feeding in temperatures as low as $-35^{\circ} \mathrm{C}$.

About a week after the original sighting the bird moved about $1.5 \mathrm{~km}$ to a different part of Pinawa, where it frequented several feeding stations, including Taylor's. It generally fed on small seeds, not taking the sunflower seeds favoured by Evening and Pine 


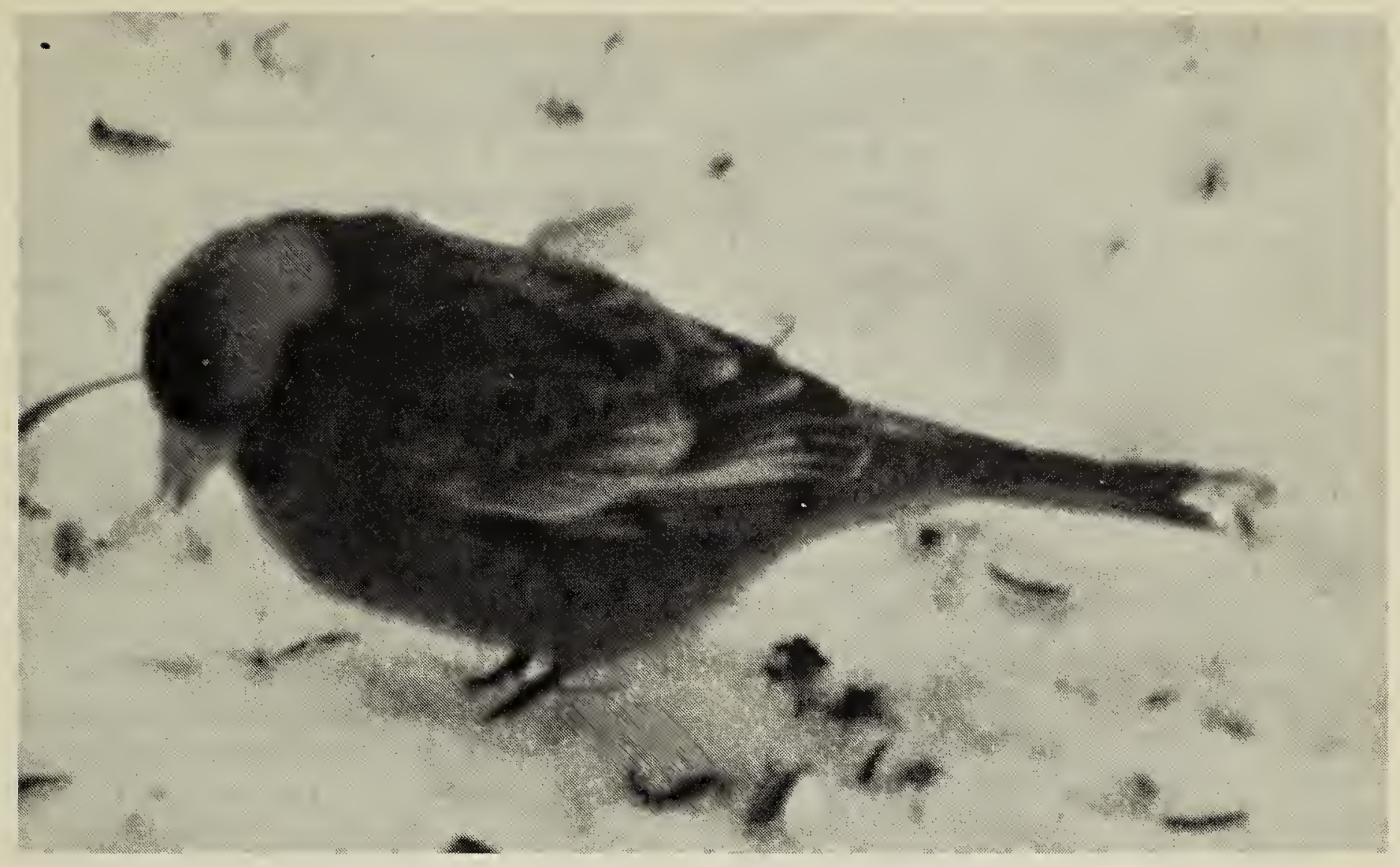

Fig. 1. Gray-crowned Rosy Finch at Pinawa, Manitoba

R. W. Knapton

Grosbeaks. It was regularly quite aggressive, and would drive away single Evening Grosbeaks which landed on a table when it was feeding. However, it usually took flight when large numbers of Evening Grosbeaks arrived, or else it was relegated to feeding on the ground adjacent to the feeder. Callin and Gross reported aggressive behaviour of Graycrowned Rosy Finches toward House Sparrows. ${ }^{314}$ Although the Graycrowned Rosy Finch is primarily a ground-feeding species, R. Zach watched the Pinawa bird consume birch tree fruits on 26 November, and Taylor observed it foraging in the top of a mature aspen with four male Evening Grosbeaks on 26 February. Rosy finches have been noted for their seemingly fearless behaviour, readily approaching farms for grain and hay, and bird feeders where small seeds are present. ${ }^{37}$ Our observations support this description.

In the Pinawa bird, pink colouration was restricted to the edges of the wing feathers, and a suffusion in the flanks and rump. The pink was no more prominent or extensive when the bird was last closely observed on 30 March, and we conclude that it was a female.

\section{"Normal" Winter Distrlbutlon}

In winter Gray-crowned Rosy Finches migrate to lower altitudes, and move east and south from the breeding range above the timberline in western North America, where they nest on cliffs. ${ }^{4923}$ The winter range limit shown in Fig. 2 encloses, to the best of our knowledge, all localities at which flocks of 25 or more birds have been recorded. No records of more than six birds appear to have occurred east of this limit, with the exception of 22 at White Bear, Saskatchewan, during the winter of 1975$76 .{ }^{15}$

The species occurs commonly in winter at lower elevations in southern Alberta, for example, at Brooks and Ralston. ${ }^{37}$ It occurs sporadically in ex- 
treme southwestern Saskatchewan, (e.g., Eastend, Fort Walsh, Dollard, Ravenscrag, White Bear), sometimes in large numbers: e.g., 40 at Eastend, 9 March 193432; 200 at Eastend, 20 December 1940 (C. F. Holmes cited by Bent $t^{4}$; up to 100 at Eastend, and 22 at White Bear, winter 1975-76'15; 140 at Fort Walsh, 31 December 1976. ${ }^{20}{ }^{35}$ Christmas Bird Count data published in "American Birds" show that the species occurs in much of Montana in winter, and there are records as far east as Fort Peck $(40,3$ January $\left.1976^{15}\right)$ and Miles City $(81,18$ December $1976^{39}$ ). There are at least four records of substantial numbers in North Dakota, all in the extreme west of the state: 20 on 13 December 1966 in Billings County (E. Bry, fide R. E. Stewart $\left.{ }^{40}\right) ; 25$ at Bowman, 19 November $1972^{18} ; 200$ at Medora, 20 December $1975^{15}$ 33; 96 at Medora, 16 December $1978 . .^{40}$ The regular winter range of this species in South Dakota is shown by Whitney et al. to be restricted to the far west-central portion of the state. ${ }^{44}$ They cite many winter records of large numbers within this range. We show a more easterly range limit in South Dakota on the basis of records of 500 at Bacilands National Monument and 65 at Scenic. ${ }^{44}$ The "normal" winter range then apparently swings south and west to include extreme northwestern Nebraska. ${ }^{4}$

\section{Extralimital WInter Occurrence}

The circles on the map in Fig. 2 show all the extralimital occurrences of Gray-crowned Rosy Finches of which we are aware, within the area shown, and east of the "Normal winter distribution" in Saskatchewan and the Dakotas as defined above. Data for these records are given in Table 1. Nearly all of these records are of single birds, showing that they refer to wandering individuals, rather than irruptive movements of the kind associated with many other fringillids which winter in the northern Great Plains. We note however that occurrence just within the range limit, e.g., in southwestern Saskatchewan, appears to be sporadic. A disproportionate number of these records, including four of the nine Manitoba sightings, have occurred in approximately the past decade.

It is difficult to draw conclusions about the distribution of records as a function of distance from the breeding range, since the reports are strongly affected by the human demography of the region. Thus the absence of records from northern Saskatchewan and Manitoba may simply reflect the scarcity of observers. However, there is a decrease in frequency with increasing distance eastward, and the Ontario, lowa and Minnesota records probably represent the limit of wandering which may reasonably be expected to occur. There is one remarkable, well documented record from the state of Maine. ${ }^{14}$ Lawrence stated that several other specimens were present in Manitoba at one time, but their origin appears to be unknown. ${ }^{26} \mathrm{~N}$. Criddle indicated the species was rare at Aweme, but apparently no details are available. ${ }^{28}$ Virtually all extralimital records are for the period late October to early April. There is one surprisingly late record by C. S. Francis of a bird near Nipawin on 3 June 1953. ${ }^{5}$

\section{Notes On Subspecles}

Two subspecies of the Graycrowned Rosy Finch, L. t. tephrocotis and $L$. t. littoralis (formerly Hepburn's Rosy Finch ${ }^{4}$ ), are known to occur in the region of interest. They are readily distinguished in the field, littoralis having more extensive gray colouration on the head. ${ }^{4}$ The littoralis breeding range lies to the 


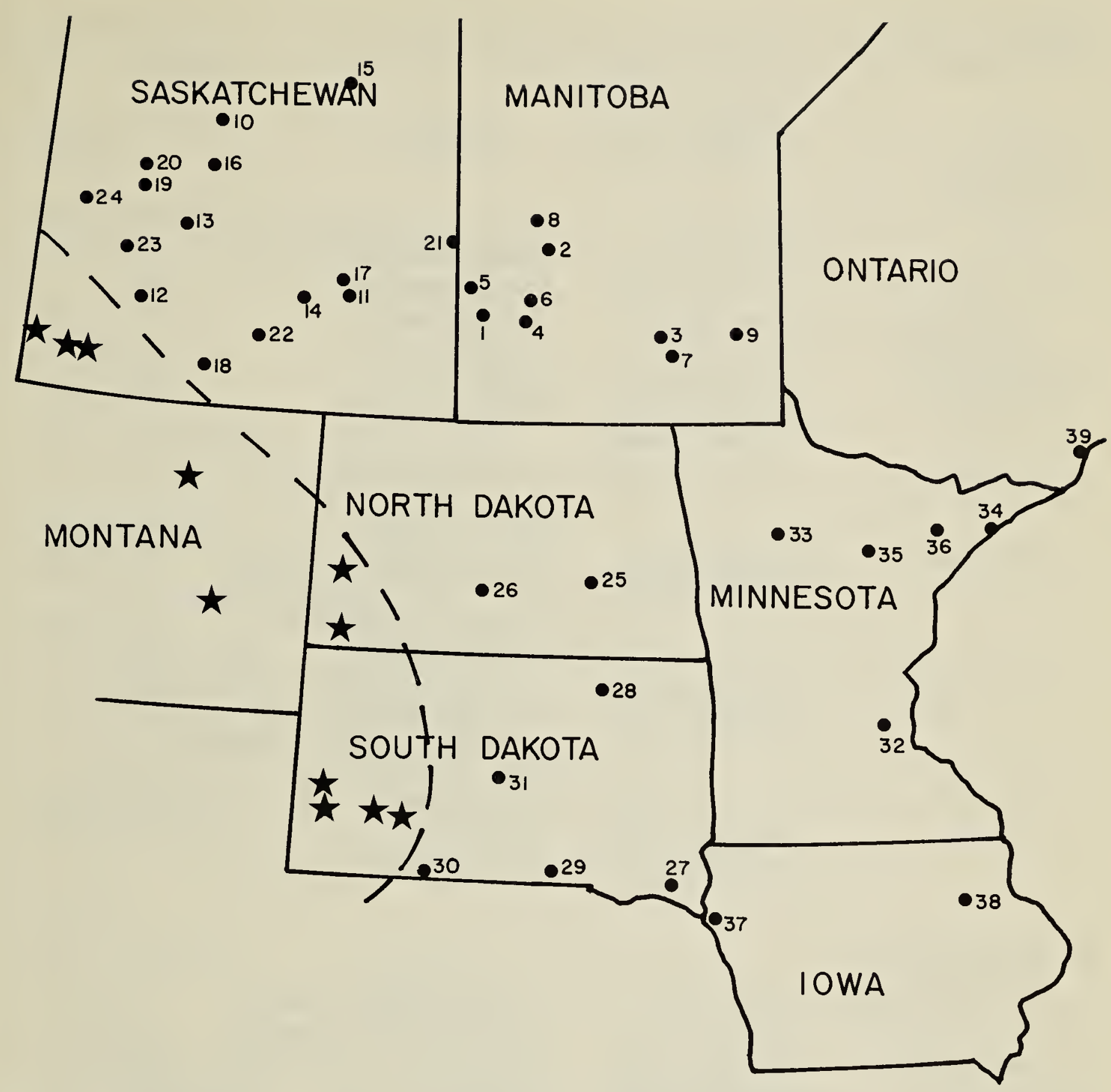

Fig. 2. Eastward extralimital records of Gray-crowned Rosy Finches (shown by circles). Stars show reported flocks of 25 or more birds within the "normal" winter distribution. Numbers refer to Table 1.

northwest of that of tephrocotis, and it thus might be expected to occur less frequently on the Great Plains. Few of the records in Table 1 are specific to race, but they appear to bear out this expectation. However, littoralis has been recorded as far east as Ontario, Manitoba and Minnesota, as well as the extraordinary Maine bird. There is one record by Potter ${ }^{32}$ of a flock of 12 littoralis birds at Ravenscrag, Saskatchewan; at least the majority of records of large flocks in southwest Saskatchewan are referable to tephrocotis.
Rosy Finches are evidently highly adaptable in being able to live from above treeline in summer, to lowlands and farmyards in winter, and in crossing wide expanses of boreal forest to reach locations such as Thunder Bay, Ontario. Pinawa is located approximately 30 kilometres east of prairie grasslands and farms, in an area of boreal forest, so that surroundings for the bird reported here were somewhat different from the open areas commonly encountered farther west in the winter. Finally, it is not known whether the recent increase in 
TABLE 1: Summary of eastward extrallmital winter records of Gray-crowned Rosy Finches.

Location

\section{A. Manitoba}
1. Birtle
2. East Bay, Lake Dauphin
3. Stonewall
4. Basswood
5. Russell
6. Erickson

7. Winnipeg

8. Winnipegosis

9. Pinawa

\section{B. Saskatchewan}

10. Carlton (House)

11. Indian Head

12. Swift Current

13. Macrorie

14. Regina

15. Nipawin

(Torch River)

16. Saskatoon

17. Fort Qu'Appelle

18. Glentworth

19. Valley Centre

20. Biggar

21. Togo

22. Spring Valley

23. White Bear

24. Kindersley
Date

Remarks

Source

Jan. 1891

18 Nov. 1922

Nov. 1939

3 Feb. 1942

2, 9 Nov. 1959;

22 Mar. 1960

13-14 Mar. 1968

22 Dec. 1977

- 8 Jan. 1978

10 Feb. to late Mar. 1978

20 Nov. 1978

- 30 Mar. 1979
One, in collection of Ernest Thompson Seton

One, apparently

L.t. tephrocotis

One seen

One.⿱㇒?

One seen

One, identified by

R. J. Walker, verified

by J. A. Crosby

One, observed by Mr. and

Mrs. W. Deans, identified

by H.W. R. Copland as

L. t. tephrocotis

One, observed by $R$. and

G. Coder, identified to subspecies from photograph as L. t. littoralis, by

W. J. Walley

One female

L. t. tephrocotis
$26,38,42$

26

8,17

27

1

16

$8,17,25$

43

This report
May 1827

"Prior to 1924"

25 Nov. 1933

26 Feb. 1938

23 Oct. 1940

"early winter"

1948

19-21 Jan. 1973

15 Nov. to

20 Dec. 1975

Winter 1975-76

early Dec.

1940

3 June 1953

20 Oct. 1962

2 Feb. to

3 Apr. 1963

30 Oct. 1963

10-12 Nov. 1973

22 Jan. 1974

Feb. 1974

17-20 Dec. 1975

Winter 1975-76

Dec. 1977
Type locality for species

"repeated observations"

Specimen "taken in district"

One seen

One seen

One specimen

One male, photographed,

Boggy Creek valley

One, photographed,

Wascana Waterfowl Park

One, $40 \mathrm{~km}$ north

One seen, several days

$4,19,41$

5,30

22

36

3,5

3,5

One seen

One seen

Two males

One littoralis seen

Four seen

One seen

Two seen, $7 \mathrm{~km}$ north

One seen

Up to 22

One and two seen
3

3

3

5,19

5,19

5,10

5

7

34

34

29

15,35

15

21 


\section{North Dakota}

25. Jamestown

26. Bismarck

D. South Dakota

27. Volin

28. Aberdeen

29. Burke

30. Lacreek NWR

31. Sheep Mountain

E. Minnesota

32. Near Minneapolis

33. Bagley, Clearwater $\mathrm{Co}$.

34. Little Marais, Lake Co.

35. Grand Rapids, Itasca Co.

36. Hoyt Lakes, St. Louis Co.

F. Lowa

37. Sioux City

38. Oelwein

G. Ontarlo

39. Thunder Bay

31 Mar. 1963

25 Feb. to

25 Mar. 1973

31 Jan. 1975

\section{H. Maine}

40. Gorham

Jan. 1979

1 Feb. 1973

26 Oct. 1973

22 Nov. 1973

3 Jan. 1889

to Mar. 1968

25 Jan. to

16 Feb. 1972

28 Oct. 1972

11 Mar. 1978

Wintered to

18 Mar. 1978
14-18 Dec. 1975

late Dec. 1960

to 15 Mar. 1961

14 Nov. 1972 to

2 Dec. 1972 to Six

about 1 Mar. 1973

late Dec. 1967

MMNH Sp. No. 216

Two

One, photographed

One ơ

13,28

One

One, photographed

(littoralis?)

One, photographed

(littoralis)

One, photographed

One, trapped, banded and photographed (littoralis)
15 Dec. 1936 to at least 10 Mar. 1937
13

13

13

6

4

24

12

44

44

44

44

44

2

11

14 extralimital sightings of this species is due to a larger number of Rosy Finches wandering east, or to a larger number of interested observers. Whichever is the case, indications certainly are that the species occurs occasionally over a wide area, and should be watched for during the winter.

\section{Acknowledgements}

We are grateful to W. J. Walley for permission to include the Winnipegosis sighting, to $R$. W. Knapton for use of his photograph, and to all of the following for their generous assistance with records and literature: M. Belcher, H. W. R. Copland, K. 
Gardner, W. E. Godfrey, M. I. and C. S. Houston, F. W. Lahrman, M. K. McNicholl, P. A. Pearce, R. W. Seabloom and R. E. Stewart. J. B. Gollop and R. W. Nero provided helpful comments on the manuscript, and D. Rondeau aided in manuscript preparation.

'ANONYMOUS. 1960. Letters. Blue Jay 18:97.

2BAILLIE, J. L. 1964. Ontario's newest birds. Ontario Field Nat. 18:1-13.

${ }^{3}$ BELCHER, M. 1980. Birds of Regina. Spec. Pub. 12, Sask. Nat. Hist. Soc., Regina.

${ }^{4}$ BENT, A. C. 1968. Life histories of North American cardinals, grosbeaks, buntings, towhees, finches, sparrows and allies. U.S. Nat. Mus. Bull. 237, part 1:358-361.

${ }^{5}$ CALLIN, E. M. 1963. Gray-crowned Rosy Finch at Fort Qu'Appelle. Blue Jay 21:57-58.

${ }^{6}$ ECKERT, K. 1978. Amer. Birds 32:1011.

'FOLKER, R. V. 1964. An observation of the western race of the Graycrowned Rosy Finch. Blue Jay 22:6.

'GARDNER, K. 1978. "Wild Wings". Winnipeg Tribune, January 28.

${ }^{\circ}$ GODFREY, W. E. 1966. The birds of Canada. Nat. Mus. Can. Bull. 203, Queen's Printer, Ottawa.

${ }^{10 G O L L O P, ~ J . ~ B ., ~ J . ~ F . ~ R O Y ~ a n d ~ R . ~ V . ~}$ FOLKER. 1963. Some 1962 bird records for the Saskatoon district. Blue Jay 21:12.

${ }^{11 G O O D W I N, ~ C . ~ E . ~ 1973 . ~ A m e r . ~ B i r d s ~}$ 27:611.

${ }^{12 G O O D W I N, ~ C . ~ E . ~ 1975 . ~ A m e r . ~ B i r d s ~}$ 29:687.

${ }^{13 G R E E N, ~ J . ~ C . ~ a n d ~ R . ~ B . ~ J A N S S E N . ~} 1975$. Minnesota birds. Univ. Minn. Press, Minneapolis.

${ }^{14}$ GROSS, A. O. 1937. Hepburn's Rosy Finch in Maine. Auk 54:396-397.

${ }^{15}$ HARRIS, W. C. and S. M. LAMONT. 1976. Amer. Birds 30:734.

${ }^{16} \mathrm{HATCH}$, D. R. M. 1968. Audubon Field
Notes 22:450.

${ }^{17} \mathrm{HATCH}$, D. 1978. "Chickadee Notes". Winnipeg Free Press, February 11.

${ }^{18}$ HOUSTON, C. S. 1973. Amer. Birds $27: 632$.

${ }^{19} \mathrm{HOUSTON}, \mathrm{C}$. S. and M. G. STREET. 1959. The birds of Saskatchewan River, Carlton to Cumberland. Spec. Pub. 2, Sask. Nat. Hist. Soc., Regina.

${ }^{20}$ HOUSTON, M. I. 1977. 36th annual Saskatchewan Christmas bird count - 1976. Blue Jay 35:21-30.

${ }^{21}$ HOUSTON, M. I. 1978. 37th annual Saskatchewan Christmas bird count 1977. Blue Jay 36:16-26.

${ }^{22}$ HOUSTON, M. I. and C. S. HOUSTON. 1980. Personal communication.

${ }^{23} \mathrm{JOHNSON}, \mathrm{R}$. E. 1965. Reproductive activities of rosy finches, with special reference to Montana. Auk 82:190205.

${ }^{24}$ KLEEP, V. M. 1978. Amer. Birds 32:1016. ${ }^{25}$ KOES, R. 1978. Amer. Birds 32:472.

${ }^{26}$ LAWRENCE, A. G. 1922. "Chickadee Notes" No. 88. Winnipeg Free Press, November 30 .

${ }^{27}$ LAWRENCE, A. G. 1942. "Chickadee Notes" No. 1090. Winnipeg Free Press, February 13

${ }^{28}$ MALEY, A. 1973. Amer. Birds 27:65.

${ }^{29}$ MAY, W. J. C. 1974. Winter bird feeding at Togo, Saskatchewan. Blue Jay $32: 181$.

${ }^{30}$ MITCHELL, H. H. 1924. Birds of Saskatchewan. Canadian Field-Nat. 38:101118.

${ }^{31}$ PETERSON, R. T. 1961. A field guide to western birds. Houghton Mifflin, Boston. 2nd ed.

${ }^{32}$ POTTER, L. B. 1935. The Rosy Finch in Saskatchewan. Condor 37:213-214.

${ }^{33}$ RANDALL, R. N. 1975. Christmas bird counts for North Dakota - 1975. Prairie Nat. 7:88-91.

${ }^{34}$ RENAUD, W. E. and D. H. RENAUD. 1975. Birds of the Rosetown-Biggar District, Saskatchewan. Spec. Pub. 9 , Sask. Nat. Hist. Soc., Regina.

${ }^{35}$ RENAUD, W. E. and G. J. WAPPLE. 1977. 
A review of Saskatchewan Christmas bird counts: 1942-1976 (part 1). Blue Jay 35:224-239.

${ }^{36}$ ROY, J. F. 1964. Birds of the Elbow. Sask. Nat. Hist. Soc., Regina.

${ }^{37}$ SALT, W. R. and J. R. SALT. 1976. The birds of Alberta. Hurtig, Edmonton.

${ }^{38}$ SETON, E. T. 1908. Recent bird records for Manitoba. Auk 25: 450-454.

${ }^{39}$ SHRYER, J. 1977. Miles City, Montana, Christmas Bird Count. Amer. Birds 31:793.
${ }^{40}$ STEWART, R. E. 1979. Personal communication.

${ }^{4}$ SWAINSON, W. and J. RICHARDSON. 1831. Birds. in Richardson, Fauna Boreali-Americana, Vol. 2.

${ }^{42}$ THOMPSON, E. E. 1893. Additions to the list of Manitoba birds. Auk 10:49-50.

${ }^{43}$ WALLEY, W. J. 1979. Personal communication.

${ }^{44}$ WHITNEY, N. R. Jr., ed. 1978. The birds of South Dakota. South Dakota Ornithologists' Union. Vermillion, S.D.

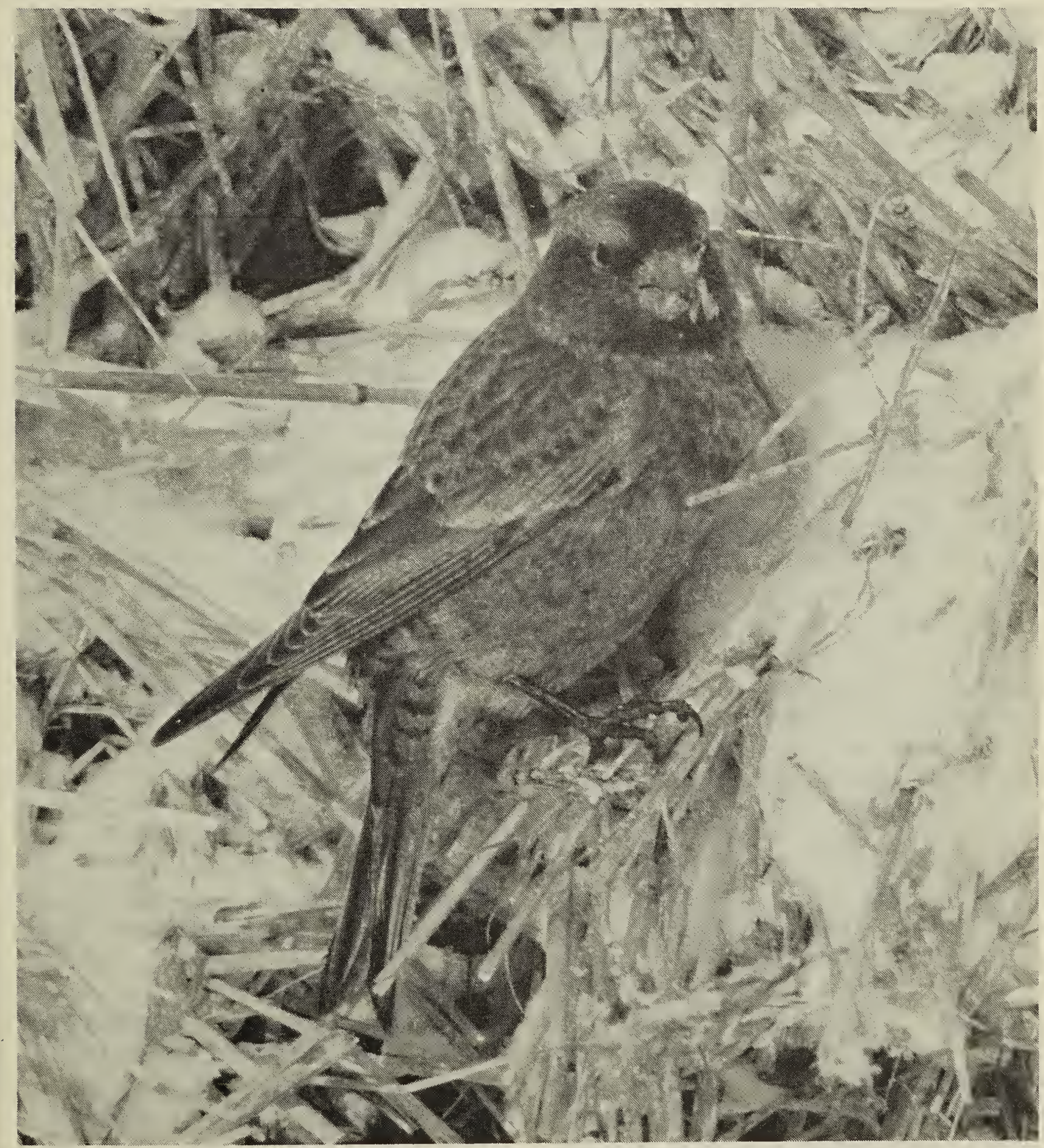

Gray-crowned Rosy Finch foraging on bail stack, Eastend, Saskatchewan, 29 December 1978. 